\title{
How Does Trade Openness Influence Budget Deficits in Developing Countries?
}

Jean-Louis Combes and Tahsin Saadi-Sedik 



\title{
IMF Working Paper
}

Fiscal Affairs Department

\section{How Does Trade Openness Influence Budget Deficits in Developing Countries?}

\author{
Prepared by Jean-Louis Combes and Tahsin Saadi-Sedik ${ }^{1}$ \\ Authorized for distribution by Gerd Schwartz
}

January 2006

\begin{abstract}
This Working Paper should not be reported as representing the views of the IMF. The views expressed in this Working Paper are those of the author(s) and do not necessarily represent those of the IMF or IMF policy. Working Papers describe research in progress by the author(s) and are published to elicit comments and to further debate.

This paper analyzes the effects of trade openness on budget balances by distinguishing the effects of natural openness from those of trade-policy induced openness. Using the GMMsystem estimator, the econometric analysis focuses on 66 developing countries during 1974-98. The results show that trade openness increases a country's exposure to external shocks regardless of its underlying causes. This reinforces the adverse effects of terms of trade instability on budget balances. However, trade openness also influences budget balances through several other channels: corruption, income inequalities, etc. The paper shows that these additional effects of natural openness and trade-policy induced openness on budget balances go in opposite directions: the former deteriorates budget balances whereas the latter improves them.
\end{abstract}

JEL Classification Numbers: H62, F02, F13

Keywords: Trade openness, Trade policy, Natural openness, Budget balances, Terms of trade instability, Developing countries, GMM-system

Author(s) E-Mail Address: tsaadisedik@imf.org; J-L.Combes@u-clermont1.fr

\footnotetext{
${ }^{1}$ This paper is forthcoming in the Journal of Development Studies. Part of this paper was written when Tahsin Saadi-Sedik was at CERDI-University of Auvergne, where Jean-Louis Combes is a professor. The authors would like to thank Gerd Schwartz, Marijn Verhoeven, Jha Raghbendra, and two anonymous referees of the Journal of Development Studies for their helpful comments; also the participants to the 58th Congress of International Institute of Public Finance (IIPF) in Helsinki, August 2002; and to the 51st Congress of the Association Française des Sciences Economiques (AFSE) in Paris, September 2002.
} 


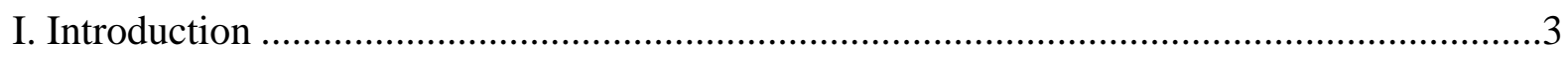

II. Theoretical Effects of Trade Openness on Budget Deficits ..........................................4

III. The Measure of Terms of Trade Instability .............................................................

IV. The Measure of the Revealed Trade Policy ...........................................................

V. The Econometric Strategy .................................................................................11

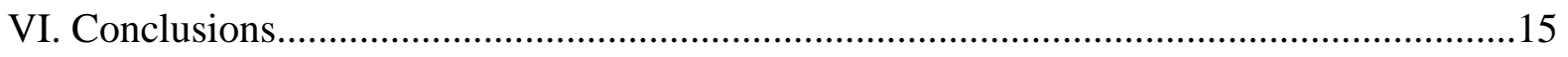

\section{Tables}

1. Correlation Between the Three Measures of Terms of Trade Instability ...........................8

2. Measuring Natural Openness and Trade Policy...........................................................10

3. Explaining Budget Surpluses.................................................................................. 14

Appendix

I. List of Countries in the Sample ........................................................................... 16

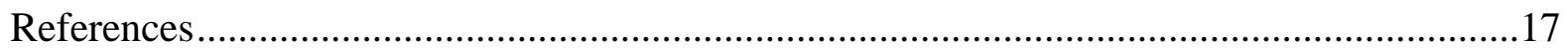




\section{INTRODUCTION}

There has been much debate on the macroeconomic consequences of trade openness for developing countries. This debate has particularly focused on the effect of trade openness on economic growth, with the dominant message being that trade openness is good for growth (Edwards, 1998 and Rodrik, 1999). A large literature also exists on the channels of transmission of trade openness to economic growth (Guillaumont, 1994 and Combes and others, 2000). Still, few studies have discussed the influence of trade openness on economic growth via budget balances. This is surprisingly neglected in the literature, particularly since the theoretical and empirical studies have provided a positive and robust relationship between budget balances and economic growth (e.g., Fischer, 1993 and Easterly, Rodriguez, and Schmidt-Hebbel, 1994).

Some authors have introduced trade openness as a control variable for budget balances. In these studies, the effect of trade openness on budget balances in some cases is contradictory. For example, Edwards and Tabellini (1991) studied the effects of political instability on fiscal policies and inflation in developing countries; they found that the variable has in some regressions a positive sign and in others a negative sign. Schuknecht (1999) analyzed fiscal policies cycles and exchange rate regimes around elections in 25 developing countries; he found that the variable of trade openness, the sum of imports and exports over GDP, has the expected positive effect on the overall budget balances, but it is not significant at conventional levels. Alesina and others (1999), in a paper on the impact of budget institutions on fiscal performance in Latin America, multiplied the rate of change in the terms of trade by the degree of openness; they found that this variable - taken as a proxy for trade opennessis not always significant.

These results may not be surprising as the authors fail to distinguish natural openness from trade-policy induced openness or outward-looking policy. Natural openness is based on structural determinants of trade openness (e.g., the size of the country and its geographical characteristics). Trade-policy induced openness is determined by decision makers. Thus, the two components of trade openness may have conflicting effects on budget balances and should be distinguished from each other.

This paper seeks to address this issue. We examine the impact of trade openness on budget balances by distinguishing the effects of natural openness from trade-policy induced openness. First, we decompose the conventional measure of trade openness (exports plus imports of goods and services in percent of GDP) into natural openness and trade-policy induced openness. We compute natural openness by estimating the level of trade openness a country should have based on its structural factors, and compute trade-policy induced openness as the difference between actual and natural openness. Second, we analyze econometrically the effects of these two components of trade openness on budget balances.

The econometric analysis focuses on 66 developing countries during 1974-98. We use the GMM-system estimator to overcome potential endogeneity issues between budget balances and trade openness. We first analyze the effect of trade openness on budget balances via its 
effect on the instability of government revenue. Then, we examine the additional effect of trade openness on budget balances (e.g., mainly through corruption and inequality). The results show that trade openness increases a country's exposure to external shocks regardless of whether trade openness is due to natural openness or to trade-policy induced openness. This reinforces the adverse effect of terms of trade instability on budget balances. The additional effects of natural openness and trade-policy induced openness have opposite signs: the former deteriorates budget balances whereas the latter improves them.

This paper is organized as follows. Section II discusses the theoretical effects of trade openness on budget balances. Section III presents our measures of terms of trade instability. Section IV computes the indicators of natural openness and trade-policy induced openness. Section V presents the data and the econometric analysis. The last section presents concluding observations.

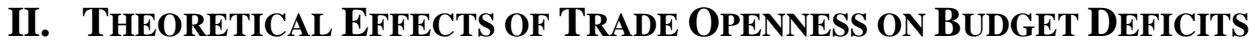

\section{A. Trade Openness and Instability of Government Revenue}

We first present two normative approaches - the tax smoothing theory and the Permanent Income Hypothesis - which argue that, on average and over a sufficient long period, the instability of government revenue has no effect on budget balances. Thus, trade openness cannot have any effect on budget balances via its effect on the instability of government revenue. Then we present two arguments - the Dutch disease hypothesis and the political pressure argument-which help explain why instability of government revenue may influence budget balances.

\section{Normative approaches}

Existing normative approaches, such as the tax smoothing theory and the Permanent Income Hypothesis, do not explain the effect of trade openness on budget balances via its effect on the instability of government revenue. According to the tax smoothing theory of Barro (1979, 1995, and 1999), Lucas and Stockey (1983), and Bohn (1990), governments use deficits and surpluses to smooth taxes. Similarly, the Permanent Income Hypothesis implies that governments may use surpluses and deficits to smooth their spending. Thus, according to these two theories, the optimal fiscal policy implies that budget deficits should be countercyclical and, on average and over a sufficiently long period, budgets should be balanced. Although both the tax-smoothing theory and the Permanent Income Hypothesis are valuable as normative theories, ${ }^{2}$ as positive theories they do not explain any effect of trade

\footnotetext{
2 Still, Barro (1985 and 1986) views the tax smoothing theory also as a positive theory and has tested the taxsmoothing model on 200 years of American and British data. The empirical evidence is broadly consistent with the basic principles of tax smoothing: debt to GNP ratios increase during wars, decrease in peacetime, and fluctuate with the business cycles. A problem with the theory is that any fiscal policy can be rationalized from a tax smoothing perspective if expectations are a "free variable" (Alesina and Perotti, 1994). Tax-smoothing could even explain the high fiscal deficits in the 1980s in the United States: suppose that in the early 1980s it
} 
openness on budget balances via its effect on the instability of government revenue. Moreover, they can not explain the high budget deficits experienced since the early 1970s.

\section{The Dutch disease hypothesis and political pressure argument}

One explanation for deviations from the predictions of the two optimal fiscal theories is that positive and negative external shocks have asymmetric effects on public finances by creating a ratchet effect in public spending. This could be explained either by the Dutch disease hypothesis (Collier and Gunning, 1999) and/or by the political pressure argument (Alesina and Perotti, 1994).

According to the Dutch disease hypothesis, governments do not increase public savings in response to positive external shocks because temporary shocks are believed to be permanent and because of the uncertainty on the duration of shocks coupled with asymmetric costs of errors. $^{3}$ In developing countries, terms of trade instability is a key determinant of a country's macroeconomic performance (Cashin and Pattillo, 2000). Many countries are prone to temporary terms of trade shocks. These shocks can lure governments into huge fiscal errors. In fact, some price shocks are clearly temporary, such as the coffee booms induced by the 1975 Brazilian frosts (Deaton, 1999). If governments were to save most of the windfall from a positive external shock, the Dutch disease hypothesis would be misplaced. However, governments often do not know how long price shocks will last. Given the high degree of uncertainty about the persistence of price shocks, the effect of trade shocks on budget balances depends in part upon whether there are asymmetries between the consequences of errors of optimism and pessimism ${ }^{4}$ (Collier and Gunning, 1999). If the cost of errors of optimism exceeds those of pessimism, then trade shocks could deteriorate budget balances.

In contrast, political economy models show that public spending could increase in response to a positive shock, even when there is certainty about the duration of shocks. Fluctuations in tax base are often large in developing countries. Thus, full tax smoothing or full consumption smoothing would imply running large budget surpluses in good times and large budget deficits in hard times. However, the ability of governments to run large budget surpluses in good times is hampered by political pressures which, although always present, gets exacerbated in times of plenty (Alesina and Perotti, 1994). Indeed, suppose that a country faces a temporary positive external shock implying temporary higher government revenue. If the government wants to save the entire windfall, it would have to resist spending pressures

became known that, with a temporary increase in military spending, the cold war could have been won and, by the 1990s military spending could be cut below the initial level in 1980. The optimal policy was to cut taxes and increase military spending in 1980s and to run deficits in the 1980s and surpluses in the 1990s.

${ }^{3}$ The uncertainty on the duration of shocks has no impacts, in average, on budget deficits if the costs of errors are symmetric.

${ }^{4}$ In this context, optimism (pessimism) could be defined by the fact that government overestimates the duration of a positive (negative) shock. 
from the public and from spending ministries. ${ }^{5}$ Each spending ministry may face a free-rider problem: its own decision to transfer spending to the future might be frustrated by the increased spending of other ministries (Collier and Gunning, 1999). Thus, during a positive external shock, each ministry has strong incentives to increase its own spending. More generally, Talvi and Végh (2000) suggest that political pressures during positive shocks imply both decreasing fiscal effort and increasing public spending. ${ }^{6}$ However, they do not take into account asymmetries between the impact of negative and positive shocks. Under a positive shock, governments increase both current and capital expenditures. Nevertheless, during a negative shock, governments could hardly reduce current expenditures. This implies a reduction in public investment and/or an increase in budget deficits.

Thus, economies that are more open face higher exposure to external shocks, reinforcing the negative relationship between terms of trade instability and budget balances. If fluctuations in the tax base are small, spending pressures do not play much of a role and full tax smoothing or full consumption smoothing will hold as approximations. In contrast, when fluctuations in the tax base are large, as is often the case in developing countries, political pressures become harder to resist and have a major impact on fiscal policy. Consequently, countries with a volatile tax base have more volatile public spending patterns and thus, through the ratchet effect, higher budget deficits.

In these circumstances the key issue is the exposure of an economy to external shocks, whether or not this is due to natural openness or trade-policy induced openness, and distinguishing between natural openness and trade-policy induced openness may not be useful. Still, one can argue that countries that have implemented outward-looking policies also have a better ability to face shocks, that is, they have higher resilience (Combes and Guillaumont, 2002) and therefore more disciplined budgets.

\section{B. Other Channels through which Trade Openness Influences Budget Deficits}

In addition to the effect of trade openness via its effect on the instability of government revenue, trade openness influences public spending and government revenue, and thus budget balances through four main other channels. First, trade openness could have an effect on budget balances via its effect on corruption. Here, natural openness and trade policy could have different effects on corruption and therefore on budget balances. Oil and mineral producing countries, which are naturally more open, are also more corrupt because of

\footnotetext{
${ }^{5}$ There is a widespread practice in volatile economies to underestimate fiscal revenues in order to prevent overspending (Talvi and Végh, 2000).

${ }^{6}$ However, procyclical fiscal policies could be explained by borrowing constraints. Potentially, budget deficits out of negative shocks might be lower, in absolute value, than budget surpluses out of positive shocks of the same duration because of the asymmetry created by borrowing constraints, particularly in developing countries. The imperfections of the credit market imply that during a positive shock, saving rates are lower than those predicted by optimal policies and during a negative shock, dissaving rates are lower too. This could explain why during a positive (negative) shock both public spending increase (decrease) and tax rates decrease (increase).
} 
availability of rents. However, countries with an outward-looking strategy have higher levels of competition, are less corrupt (Ades and Di Tella, 1999) and have higher budget balances. Second, trade openness increases income inequalities (Savvides, 1998), which enhances the demand of public goods (Alesina and Perotti, 1996) and, simultaneously, reduces the ability of governments to collect taxes. Third, trade policy could reduce government revenue in the short run (Bevan, 1999), which could occur when increases in openness result from a reduction in tariffs. ${ }^{7}$ However, for a given level of tariffs, government revenue from trade taxes is an increasing function of trade openness. Thus, in the long run, trade policy can increase government revenue. Finally, trade openness is expected to be positively correlated with budget balances as the leakage of demand abroad and resulting costs from external payment difficulties make high budget deficits less attractive than in less-trade oriented countries (Lindbeck, 1976).

\section{The Measure of Terms OF Trade InSTABILITY}

In this study, we use an approach close to that used by Lensink, Bo, and Sterken (1999). In empirical studies there are two broad approaches available to measure instability: ex-post and ex-ante approaches. The ex-post approach constructs instability measures based on historical data. The ex-ante approach constructs instability measures based on survey data. In practice, because of availability of data, most of the studies apply the ex-post approach.

We compute the terms of trade instability because we are interested in the impact of exogenous trade shocks on budget balances. ${ }^{8}$ This allows us to avoid the problem of the endogeneity of variables reflecting the instability of quantities such as the instability of the real value of exports. To measure the instability of the terms of trade, we estimate a mixed function, combining a nonlinear deterministic trend and a stochastic trend:

$$
\text { tot }_{t}=\alpha+\beta \text { tot }_{t-1}+\delta t+\lambda t^{2}+\varepsilon_{t}
$$

where

$$
\begin{aligned}
& \text { tot }=\text { terms of trade, } \\
& t=\text { time, } \\
& \mathcal{E}_{\mathrm{t}}=\text { the random component, and } \\
& \alpha, \beta, \delta \text { and } \lambda=\text { parameters to be estimated. }
\end{aligned}
$$

We compute the terms of trade instability, defined as the square of residuals of equation (1) in three possible ways:

\footnotetext{
${ }^{7}$ Nevertheless, replacing nontariff barriers by tariffs can mitigate the negative impact of trade liberalization.

${ }^{8}$ The data for terms of trade of goods and services (1995=100) come from World Bank Global Development Network (GDN).
} 
(a) First, we estimate the equation on the whole sample for each country (1965-98). The problem with this procedure is that agents do not have the information on the whole period. For example, in 1974, they do not know what will happen in 1979.

(b) Second, we estimate the equation for a rolling ten-year period and keep the square of the residual of the last year as a measure of instability of terms of trade. For example, we do the regression for 1965-74, and keep the residual for 1974; then we do the regression for 1966-75 and keep the residual for 1975, and so on. A problem with this approach is that one supposes that agents have no memory.

(c) Third, we estimate the equation by supposing that agents have memory (our preferred approach). For example, we perform the regression for 1965-74, keeping the residual for 1974, then run the regression for 1965-75, keeping the residual for the period 1975, and so on. The beginning of the period is always 1965.

The three instability indicators are averaged over the following sub-periods: 1975-78, 1979-82, 1983-86, 1987-90, 1991-94, and 1995-98. The different measures of instability are highly correlated (Table 1$)$ :

Table 1. Correlation Between the Three Measures of Terms of Trade Instability

\begin{tabular}{cccc}
\hline & (a) & (b) & (c) \\
\hline (a) & 1 & & \\
(b) & 0.66 & 1 & 1 \\
(c) & 0.79 & 0.81 & 1 \\
\hline
\end{tabular}

Note: We compute the terms of trade instability only for developing countries (see the sample in Appendix).

From here we use measure (c) for the terms of trade instability. However, to perform a robustness test, we compute also a synthetic instability measure, using Principal Component Analysis, based on the three original measures. ${ }^{9}$

\section{The Measure of the Revealed Trade Policy}

In this study, we use the revealed measure of trade policy as in Chenery and Syrquin (1975), Guillaumont and Guillaumont Jeanneney (1988), and Combes and Guillaumont (2002). Trade openness (imports plus exports of goods and services as a percentage of GDP) is decomposed into natural openness and trade-policy induced openness. Natural openness is computed by estimating what level of trade openness a country should have based on its structural factors. Trade-policy induced openness is the difference between the trade openness and the natural openness.

\footnotetext{
${ }^{9}$ We thank an anonymous referee of the Journal of Development Studies for suggesting this idea to us.
} 
Our indicator of trade policy avoids using subjective weightings in order to combine several policy instruments. There is no perfect trade policy measure to compare countries at a point in time and even to compare the trade policy of a given country at different points in time (Rose, 2002). According to Baldwin (1989), existing measures of the degree to which governments restrict trade generally fall into two types: measures of incidence of trade restrictions and measures of their effects on outcome. The former are based on direct observation of trade policy instruments. The latter assess trade policies by how much actual outcome deviates from what the outcome would have been without trade barriers.

A large set of incidence-based indicators exists in the literature, including the average level of tariffs, the level of export taxes, and the percentage of imports subject to nontariff restrictions. Each of these measures is partial, since a trade policy results from the way that all policy instruments are used (Combes and Guillaumont, 2002). That is why some authors, like Sachs and Warner (1995) classify countries into open and closed countries by combining some of these partial trade policy instruments. Nevertheless, Rodriguez and Rodrik (1999) emphasize the limits of the Sachs and Warner indicator. In particular, they argue that the weightings used to combine policy instruments are subjective.

Thus, some authors use outcome indicators in terms of prices (Dollar, 1992) and quantities. An indicator of quantities can be the ratio of exports plus imports of goods and services in percent of GDP. This indicator has the advantage of being easily calculable from available data for a broad range of countries over long periods. However, it is not only determined by trade policy but also by structural factors.

In this paper, we compute natural openness as the fitted value derived from a regression of actual trade openness on structural variables. Then, the residual of this regression is labeled trade-policy induced openness (Table 2). This measure is an indicator of relative trade-policy induced openness since the mean of the residuals equals zero. Therefore, it depends on sample selection. ${ }^{10}$ Moreover, we follow standard practice and compute four-year average as to smooth over some of the cyclical features of the data. The structural variables are the following. Larger countries are less specialized and are less open, with a country's size measured by the logarithm of its population. More developed countries are probably more competitive in a broad range of products. Therefore, using GDP per capita as an indicator of development, countries with a high GDP per capita are expected to have higher levels of trade openness. The third variable is a "landlocked" dummy, which reflects roughly the cost of transport; all other things equal, if a country is landlocked, it is less open.

\footnotetext{
${ }^{10}$ If we change the sample, a relatively more open country in the first sample could become relatively more closed in the second and vice versa.
} 
Table 2. Measuring Natural Openness and Trade Policy

\begin{tabular}{|c|c|c|c|c|c|c|c|}
\hline $\begin{array}{l}\text { The dependent variable is } \\
\text { trade openness }\end{array}$ & 1 & 2 & 3 & 4 & 5 & 6 & 7 \\
\hline Intercept & $\begin{array}{c}256.58 \\
(13.65)^{* * *}\end{array}$ & $\begin{array}{c}294.77 \\
(11.45)^{* * *}\end{array}$ & $\begin{array}{c}270.54 \\
(10.73)^{* * *}\end{array}$ & $\begin{array}{c}267.95 \\
(10.85)^{* * *}\end{array}$ & $\begin{array}{c}233.51 \\
(9.40)^{* * *}\end{array}$ & $\begin{array}{c}272.34 \\
(9.07)^{* * *}\end{array}$ & $\begin{array}{c}289.49 \\
(10.78)^{* * *}\end{array}$ \\
\hline Lag of GDP per capita & $\begin{array}{c}4.54 \\
(2.63)^{* * *}\end{array}$ & $\begin{array}{c}2.55 \\
(1.38)\end{array}$ & $\begin{array}{c}4.35 \\
(2.50)^{* * *}\end{array}$ & $\begin{array}{c}3.76 \\
(1.69) *\end{array}$ & $\begin{array}{c}1.11 \\
(0.57)\end{array}$ & $\begin{array}{c}3.44 \\
(1.67)^{*}\end{array}$ & $\begin{array}{l}2.54 \\
(1.37)\end{array}$ \\
\hline Population in log & $\begin{array}{c}-14.01 \\
(-19.90)^{* * *}\end{array}$ & $\begin{array}{c}-14.99 \\
(-16.88)^{* * *}\end{array}$ & $\begin{array}{c}-14.5 \\
(-16.14)^{* * *}\end{array}$ & $\begin{array}{c}-14.29 \\
(-16.20)^{* * *}\end{array}$ & $\begin{array}{c}-11.14 \\
(-11.47)^{* * *}\end{array}$ & $\begin{array}{c}-14.50 \\
(-13.94)^{* * *}\end{array}$ & $\begin{array}{c}-15.00 \\
(-16.90)^{* * *}\end{array}$ \\
\hline Landlocked dummy & $\begin{array}{c}-4.04 \\
(-1.06)\end{array}$ & $\begin{array}{c}-7.51 \\
(-2.26)^{* * *}\end{array}$ & & $\begin{array}{l}-5.21 \\
(-1.31)\end{array}$ & $\begin{array}{c}-11.22 \\
(-2.77)^{* * *}\end{array}$ & $\begin{array}{l}-5.76 \\
(-1.50)\end{array}$ & $\begin{array}{c}-7.51 \\
(-2.26)^{* * *}\end{array}$ \\
\hline Mines & & & & & $\begin{array}{c}0.45 \\
(2.93)^{* * *}\end{array}$ & & \\
\hline $\begin{array}{l}\text { Dummy for Tropical } \\
\text { Countries }\end{array}$ & & $\begin{array}{c}-9.79 \\
(-2.58)^{* * *}\end{array}$ & $\begin{array}{c}-7.79 \\
(-2.03)^{* *}\end{array}$ & & & $\begin{array}{c}-9.61 \\
(-2.36)^{* * *}\end{array}$ & $\begin{array}{c}-9.80 \\
(-2.58)^{* * *}\end{array}$ \\
\hline Latitude in log & & & & $\begin{array}{l}-3.60 \\
(-1.48)\end{array}$ & & & \\
\hline Squared latitude in log & & & & $\begin{array}{l}1,138 \\
(1,31)\end{array}$ & & & \\
\hline $\begin{array}{l}\text { Rate of change of terms } \\
\text { of trade }\end{array}$ & & & & & & $\begin{array}{l}11.40 \\
(1.11)\end{array}$ & \\
\hline $\begin{array}{l}\text { Average growth of } \\
\text { OECD countries }\end{array}$ & & & & & & $\begin{array}{c}3.02 \\
(1.13)\end{array}$ & $\begin{array}{c}2.10 \\
(1.13)\end{array}$ \\
\hline Number of observations & 376 & 376 & 376 & 370 & 261 & 335 & 376 \\
\hline Adjusted $\mathrm{R}^{2}$ & 0.49 & 0.50 & 0.50 & 0.49 & 0.41 & 0.45 & 0.50 \\
\hline
\end{tabular}

Note: t-statistics are in brackets. Standard errors are corrected for heteroskedasticity; ${ }^{* * *}$ : coefficient significant at 1 percent level, **: coefficient significant at 5 percent level, *: coefficient significant at 10 percent level. All variables are four-year averages, with sub-periods being 1975-78, 1979-82, 1983-86, 1987-90, 1991-94, and 1995-98.

We first compute natural openness by regressing observed trade openness on the three variables discussed above (column 1). Two of the variables (the country size and the development indicator) have the expected sign and are significant at 1 percent level, while the dummy for landlocked countries is insignificant. The adjusted $\mathrm{R}^{2}$ is close to 50 percent.

We then add to the regressions other independent variables that supposed in the literature to be important in explaining natural openness (columns 2-7). However, adding these variables does not enhance the adjusted $\mathrm{R}^{2}$. When we add exports of mineral and fuel in percent of GDP (Mines), we lose many observations because of data availability (column 5). The rate of change of the terms of trade and the variable reflecting the current world situation (computed as the average rate of growth in OECD-Organization for Economic Co-operation and Development - member countries) are not significant at conventional levels (columns 6 and 7). In the same way, the latitude and the squared latitude, introduced to capture the climatic factors, do not improve significantly the adjusted $\mathrm{R}^{2}$. 
We then replaced the "landlocked" dummy with a zero-one dummy for "tropical countries" (column 3). ${ }^{11}$ In this regression, all variables have the expected sign and are significant at the 1 percent level. Thus in the subsequent tests, we will use column 3.

\section{THE ECONOMETRIC STRATEGY}

To estimate the influence of trade openness on budget surpluses, we use a panel data analysis. Each country has six observations: 1975-78, 1979-82, 1983-86, 1987-90, 1991-94, and 1995-98. The sample includes all developing countries for which we have the required data (see Appendix). ${ }^{12}$ Our model can be summarized as follows:

$$
s_{i t}=\sum_{j=1}^{K} \theta_{j} x_{i t}^{j}+u_{i t}
$$

where

$u_{i t}=\alpha_{i}+e_{i t}$,

$\alpha=$ country-specific effect,

$\mathrm{e}=$ the error term,

$i=1, \ldots, N$ (index of country),

$t=1, \ldots, T$ (index of time),

$s_{\text {it }}=$ budget surpluses,

$x_{i t}^{j}=j^{\text {th }}$ independent variable, $j=1, \ldots, K$, and

$\theta_{j}=$ parameters to be estimated.

\section{The data}

Data on government budget surpluses are drawn from IFS (International Financial Statistics), GFS (Government Financial Statistics) and WDI (World Development Indicators). The dependent variable is overall budget surpluses excluding external grants in percent of GDP. This measure is more appropriate for developing countries than conventional overall budget surpluses including external grants. While grants represent a high proportion in government revenue in developing countries, they can vary significantly from year to year depending on donor support. Their inclusion would give an inappropriate

\footnotetext{
11 The data for tropical dummy come from World Bank Global Development Network (GDN).

12 The data are not available for all countries on the whole period, so we used an unbalanced panel. Each country, retained in the sample, has at least two sub-periods.
} 
signal of their permanence. However, to test for robustness, we also use conventional budget surpluses including external grants.

As noted earlier, we have three variables that reflect trade openness: observed trade openness in percent of GDP, natural openness, and trade-policy induced openness (based on column 3, Table 2). We also have three weighted variables: each of these three measures of trade openness times the terms of trade instability.

The other control variables are as follows. The lagged dependent variable is expected to have a positive coefficient, as governments are constrained with the current budget helping to determine the next period's budget position. This inertia provides stability and predetermines fiscal deficit pattern (Schuknecht, 1999). The degree of urbanization is expected to have a positive effect on fiscal surplus, as it is relatively easier to tax urban than rural population (Edwards and Tabellini, 1991). The sign of GDP per capita is expected to be positive. Indeed, more developed countries have probably more the ability to design efficient fiscal systems. The inflation rate could have many effects on public finances thus on budget balances. As some of these effects clearly offset each other, it is often difficult to predict the net effect of inflation on budget deficit (Catão and Terrones, 2001). However, inflation is included because in many studies it is supposed to be an important determinant of budget deficits.

\section{The econometric issues}

Estimating budget surplus equations forces us to confront two important econometric issues. First, some independent variables are likely to be endogenous to budget surpluses, at least in the short run. Second, we introduce the lagged dependent variable as a right hand side variable. With a fixed-effects estimator this variable is, by construction, correlated with the error term and therefore endogenous. We tackle these problems in two ways: (i) we work with four-year averages of the data, which eliminates some of the short-run cyclical simultaneity between budget surpluses and some independent variables, and (ii) we use Generalized Method of Moments (GMM) estimators.

The usual method of dealing with the country-specific effects, in the context of panel data, has been to work with first-order differences (Anderson and Hsiao, 1981). The GMM estimators allow controlling for both unobserved country-specific effects and potential endogeneity of the explanatory variables. Arellano and Bond (1991) present a first-difference GMM estimator. However, there are conceptual and statistical shortcomings with this estimator. ${ }^{13}$ Thus, we use an alternative system estimator that reduces the potential biases and imprecision associated with the usual difference estimators (Arellano and Bover, 1995 and Blundell and Bond, 1998). The alternative estimator combines in one system, the regressions in difference and the regressions in level.

\footnotetext{
${ }^{13}$ The first difference estimator exacerbates the bias due to errors in variables (Griliches and Hausman, 1985).
} 
We control for endogeneity by using "internal instruments," that is, instruments based on lagged values of the explanatory variables like in Loayza, Schmidt-Hebbel, and Servén (2000). We adopt the assumption of weak exogeneity of the explanatory variables, in the sense that they are assumed uncorrelated with future realizations of the error terms. ${ }^{14}$ Thus, the lagged levels of the variables may be used as instruments in the regressions in difference and the lagged differences of the variables could be used as instruments in the regressions in level. Then the effect of a given variable on budget surpluses is referred to the association between the exogenous component of that variable and budget surpluses. We do not impose any restriction on the maximum number of lags of variables. Since T (index of time) is small, this is not a problem.

\section{The results}

The consistency of the estimator depends on whether lagged values of explanatory variables are valid instruments. The criteria for the selection of instruments are two specification tests (Arellano and Bond, 1991). With the Sargan test, we do not reject the null hypothesis of the overall validity of instruments' orthogonality conditions (over-identifying restrictions). The second test is about the serial correlation of residuals. Firstly, we reject the null hypothesis of no first-order serial correlation of differenced residuals (AR(1) test) and secondly, we do not reject the null hypothesis of no second-order serial correlation of differenced residuals (AR(2) test). Thus, the residuals are serially uncorrelated and we conclude that orthogonality conditions are correct.

The results are reported in Table 3. The variable trade openness is not significant (column 1); this result suggests that the two components of observed trade openness may have opposed effects. The weighted variable (trade openness*instability), defined as observed trade openness times the terms of trade instability has the expected sign and is significant suggesting that more open countries tend to have higher exposure to external shocks and have lower budget surpluses. For a given level of terms of trade instability, economies that are more open tend to have higher budget deficits. The variable reflecting the instability is not significant, suggesting that terms of trade instability affect the budget balance through the trade openness.

\footnotetext{
${ }^{14}$ However, some variables could be strictly exogenous.
} 
Table 3. Explaining Budget Surpluses

\begin{tabular}{|c|c|c|c|c|c|c|}
\hline $\begin{array}{l}\text { The dependent variable is } \\
\text { budget surpluses }\end{array}$ & (1) & (2) & (3) & (4) & (5) & (6) \\
\hline Intercept & $\begin{array}{c}-23.20 \\
(-2.88)^{* * *}\end{array}$ & $\begin{array}{c}-25.88 \\
(-3.46)^{* * *}\end{array}$ & $\begin{array}{c}-29.51 \\
(-3.83)^{* * *}\end{array}$ & $\begin{array}{c}-31.00 \\
(-3.96)^{* * *}\end{array}$ & $\begin{array}{c}-35.90 \\
(-4.66)^{* * *}\end{array}$ & $\begin{array}{c}-7.56 \\
(-2.32)^{* *}\end{array}$ \\
\hline Lag of surpluses & $\begin{array}{c}0.55 \\
(5.75)^{* * *}\end{array}$ & $\begin{array}{c}0.53 \\
(3.73)^{* * *}\end{array}$ & $\begin{array}{l}0.59 \\
(7.31)^{* * *}\end{array}$ & $\begin{array}{c}0.28 \\
(1.71)^{*}\end{array}$ & $\begin{array}{c}0.30 \\
(2.52)^{* * *}\end{array}$ & $\begin{array}{c}0.18 \\
(2.25)^{* *}\end{array}$ \\
\hline Log of urban population & $\begin{array}{c}2.54 \\
(0.55)\end{array}$ & $\begin{array}{c}2.82 \\
(2.20)^{* *}\end{array}$ & $\begin{array}{c}0.22 \\
(0.19)\end{array}$ & $\begin{array}{c}3.85 \\
(1.82)^{*}\end{array}$ & $\begin{array}{c}4.18 \\
(2.22)^{* *}\end{array}$ & $\begin{array}{c}1.85 \\
(1.80)^{*}\end{array}$ \\
\hline Log of GDP per capita & $\begin{array}{c}2.08 \\
(0.66)\end{array}$ & $\begin{array}{c}1.64 \\
(1.61)^{*}\end{array}$ & $\begin{array}{c}3.68 \\
(2.71)^{* * *}\end{array}$ & $\begin{array}{c}1.28 \\
(0.60)\end{array}$ & $\begin{array}{c}1.98 \\
(1.60)\end{array}$ & $\begin{array}{l}-0.20 \\
(-0.33)\end{array}$ \\
\hline Log of inflation & $\begin{array}{l}-0.35 \\
(-0.87)\end{array}$ & $\begin{array}{l}-0.29 \\
(-0.94)\end{array}$ & $\begin{array}{c}-0.48 \\
(-1.44)\end{array}$ & $\begin{array}{c}-0.76 \\
(-1.46)\end{array}$ & $\begin{array}{c}-0.31 \\
(-0.67)\end{array}$ & $\begin{array}{l}-0.48 \\
(-1.45)\end{array}$ \\
\hline Trade openness*instability & $\begin{array}{l}-0.00005 \\
(-1.90)^{* *}\end{array}$ & & & & & \\
\hline Instability & $\begin{array}{l}0.001 \\
(1.08)\end{array}$ & $\begin{array}{l}-0.003 \\
(-1.48)\end{array}$ & $\begin{array}{c}0.001 \\
(0.958)\end{array}$ & $\begin{array}{l}-0.003 \\
(-0.785)\end{array}$ & $\begin{array}{l}-0.10 \\
(-0.294)\end{array}$ & $\begin{array}{l}-0.0006 \\
(-0.528)\end{array}$ \\
\hline Trade openness & $\begin{array}{l}-0.004 \\
(0.99)\end{array}$ & & & & & \\
\hline $\begin{array}{l}\text { Trade-policy induced } \\
\text { openness }\end{array}$ & & $\begin{array}{c}0.08 \\
(2.12) * *\end{array}$ & & $\begin{array}{c}0.06 \\
(1.90)^{*}\end{array}$ & $\begin{array}{c}0.11 \\
(2.04)^{* *}\end{array}$ & $\begin{array}{c}0.09 \\
(3.20)^{* * *}\end{array}$ \\
\hline Natural openness & & & $\begin{array}{c}-0.03 \\
(-2.12)^{* *}\end{array}$ & $\begin{array}{c}-0.03 \\
(-1.76)^{*}\end{array}$ & & \\
\hline $\begin{array}{l}\text { Trade-policy induced } \\
\text { openness*instability }\end{array}$ & & $\begin{array}{l}-0.0002 \\
(-1.92)^{* *}\end{array}$ & & $\begin{array}{l}-0.0003 \\
(-1.82)^{*}\end{array}$ & $\begin{array}{c}-0.04 \\
(-2.18)^{* *}\end{array}$ & $\begin{array}{c}-0.00009 \\
(-1.72)^{*}\end{array}$ \\
\hline Natural openness*instability & & & $\begin{array}{l}-0.00004 \\
(-1.66)^{*}\end{array}$ & $\begin{array}{l}-0.0001 \\
(-2.05)^{* *}\end{array}$ & & \\
\hline $\begin{array}{l}\text { Number of observations } \\
\text { Sargan test: p-value }\end{array}$ & $\begin{array}{c}261 \\
{[0.37]}\end{array}$ & $\begin{array}{c}261 \\
{[0.27]}\end{array}$ & $\begin{array}{c}261 \\
{[0.77]}\end{array}$ & $\begin{array}{c}260 \\
{[0.99]}\end{array}$ & $\begin{array}{c}258 \\
{[0.38]}\end{array}$ & $\begin{array}{c}264 \\
{[0.18]}\end{array}$ \\
\hline AR(1) test : p-value & {$[0.03]$} & {$[0.02]$} & {$[0.01]$} & {$[0.12]$} & {$[0.02]$} & {$[0.02]$} \\
\hline $\mathrm{AR}(2)$ test : $\mathrm{p}$-value & {$[0.91]$} & {$[0.67]$} & {$[0.74]$} & {$[0.52]$} & {$[0.29]$} & {$[0.20]$} \\
\hline Pseudo- $\mathrm{R}^{2}$ & 0.61 & 0.65 & 0.68 & 0.56 & 0.40 & 0.11 \\
\hline
\end{tabular}

Notes: t-statistics are in brackets. Times dummies are introduced but not shown in the Table t-statistics are in bracket. Standard errors are corrected for heteroskedasticity. ***: coefficient significant at 1 percent level, **: coefficient significant at 5 percent level, * : coefficient significant at 10 percent level. All variables are fouryear average. The sub-periods are 1975-78, 1979-82, 1983-86, 1987-90, 1991-94, and 1995-98.

When we introduce the variable trade policy beside the weighted variable of openness and the instability, its sign is positive and is significant (column 2), suggesting that trade policy has other effects on budget balances than those through its effects on the instability of government revenue. An outward looking strategy exerts a disciplining effect on government budgets, while natural openness has a negative effect on budget surpluses (column 3).

The additional effects on budget balances of natural openness and trade policy are opposed. The negative effect of natural openness could be explained either by its effect on corruption or by the fact that a more naturally open country could have smaller borrowing constraints, 
that is to say higher access to foreign capital. The natural openness times instability and trade policy times instability both have an adverse effect on budget balances. Thus, what is important is an economy's exposure to external shocks, whether the exposure is due to natural openness or to trade-policy induced openness. Similar results are obtained when variables trade-policy induced openness, natural openness, their respective interaction terms, and the instability are introduced in the same regression (column 4).

As robustness tests, we do two things: (i) use an indicator of terms of trade instability based on the Principal Component Analysis, the results are shown in column 5; both variables reflecting trade openness keep their sign and are significant and (ii) use another definition of budget surpluses, namely conventional budget surpluses with external grants; and generally speaking, the results do not change (column 6).

\section{ConCLUSIONS}

While in theory, the net effect of trade openness on budget balances is ambiguous, empirically, it is quite clear. Trade openness increases a country's exposure to external shocks regardless of whether this is due to natural openness or to trade-policy induced openness. This in turn tends to reinforce the adverse impact of terms of trade instability. Additionally, trade openness affects budget balances directly, and here the effects of natural openness and trade-policy induced openness go in opposite directions: contrary to natural openness, trade-policy induced openness improves budget balances.

Governments, including in developing countries, may often resist liberalizing their trade regimes, arguing that their budget situation is already difficult and reducing tariffs will lead to larger budget deficits. This study has shown that, even if trade openness increases a country's exposure to external shocks and thereby adversely affects its budget balances, an outward looking policy strategy should lead to an overall strengthening of its budget balances.

To reduce the adverse effects of trade openness on budget balances, a country should design sound budget institutions and efficient fiscal administrations. The latter could help reduce the effects of Dutch disease and could insulate public spending from political pressures. Also, an outward looking strategy may exert a disciplining influence on political decision makers to improve macroeconomic policies.

Finally, an outward looking strategy would also be a source of greater competitiveness, especially by insulating decision makers from the pressure of particular interest groups. In addition, an outward looking strategy, by reducing corruption, could potentially lead to designing sounder budget system and more efficient fiscal administrations. 


\section{List of Countries in the Sample}

\begin{tabular}{|l|l|l|}
\hline Argentina & Ghana & Pakistan \\
\hline Bolivia & Guatemala & Panama \\
\hline Botswana & Haiti & Papua New Guinea \\
\hline Brazil & Hungary & Paraguay \\
\hline Bulgaria & India & Peru \\
\hline Burkina Faso & Indonesia & Philippines \\
\hline Burundi & Iran, Islamic Republic of & Senegal \\
\hline Cameroon & Jamaica & Seychelles \\
\hline Chad & Jordan & Sierra Leone \\
\hline Chile & Kenya & Sri Lanka \\
\hline China & Korea, Republic of & St. Lucia \\
\hline Colombia & Lesotho & St. Vincent and the Grenadines \\
\hline Congo, Dem. Rep. of & Madagascar & Swaziland \\
\hline Costa Rica & Malaysia & Thailand \\
\hline Côte d'Ivoire & Mauritius & Togo \\
\hline Dominican Republic & Mexico & Trinidad and Tobago \\
\hline Ecuador & Morocco & Tunisia \\
\hline Egypt, Arab Republic of & Namibia & Turkey \\
\hline Ethiopia & Nepal & Uruguay \\
\hline Fiji & Nicaragua & Venezuela \\
\hline
\end{tabular}




\section{REFERENCES}

Ades, Alberto, and Rafael Di Tella, 1999, "Rent, Competition, and Corruption,” American Economic Review, Vol. 89, No. 4, pp. 982-93.

Alesina, Alberto, Ricardo Hausmann, Rudolf Hommes, and Ernesto Stein, 1999, "Budget Institutions and Fiscal Performance in Latin America,” Journal of Development Economics, Vol. 59, No. 2, pp. 253-73.

Alesina, Alberto, and Roberto Perotti, 1994, "The Political Economy of Budget Deficits," IMF Working Paper No. 94/85 (Washington: International Monetary Fund). , 1996, “Income Distribution, Political Instability, and Investment,” European Economic Review, Vol. 40, No. 6, pp. 1203-28.

Anderson, Todd W., and Cheng Hsiao, 1981, "Estimation of Dynamic Models with Error Components,” Journal of the American Statistical Association, Vol. 76, pp. 598-606.

Arellano, Manuel, and Stephen R. Bond, 1991, "Some Tests of Specification for Panel Data: Monte Carlo Evidence and an Application to Employment Equations,” Review of Economic Studies, Vol. 58, No. 2, pp. 277-97.

Arellano, Manuel, and Olympia Bover, 1995, “Another Look at the Instrumental-Variable Estimation of Error-Components Models,” Journal of Econometrics, Vol. 68, No. 1, pp. 29-51.

Baldwin, Robert E., 1989, “Measuring Nontariff Trade Policies,” NBER Working Paper No. 2978 (Cambridge, Massachusetts: National Bureau of Economic Research).

Barro, Robert J., 1979, “On the Determination of the Public Debt,” Journal of Political Economy, Vol. 87, No. 5, pp. 940-71.

, 1985, "Government Spending, Interest Rates, Prices, and Budget Deficits in the United Kingdom, 1730-1918,” University of Rochester Working Paper.

, 1986, “U.S. Deficits Since World War I,” Scandinavian Journal of Economics, Vol. 88, No. 1, pp. 195-222.

, 1995, “Optimal Debt Management,” NBER Working Paper No. 5327 (Cambridge, Massachusetts: National Bureau of Economic Research).

, 1999, “Notes on Optimal Debt Management,” Journal of Applied Economics, Vol. 2, No. 2, pp. 281-89. 
Bevan, David, 1999, “Trade Liberalization and the Budget Deficit,” Journal of Policy Modeling, Vol. 21, No. 6, pp. 653-94.

Blundell, Richard, and Stephen R. Bond, 1998, "Initial Conditions and Moment Restrictions in Dynamic Panel Data Models,” Journal of Econometrics, Vol. 87, No. 1, pp. 115-43.

Bohn, Henning, 1990, “Tax Smoothing with Financial Instruments,” American Economic Review, Vol. 80, No. 5, pp. 1217-30.

Cashin, Paul, and Catherine Pattillo, 2000, “Terms of Trade Shocks in Africa: Are They Short-Lived or Long-Lived?” IMF Working Paper No. 00/72 (Washington: International Monetary Fund).

Catão, Luis, and Marco Terrones, 2001, "Fiscal Deficits and Inflation: A New Look at the Emerging Market Evidence,” IMF Working Paper No. 01/74 (Washington: International Monetary Fund).

Chenery, Hollis B., and Moshe Syrquin, 1975, Patterns of Development 1950-1970 (Oxford and New York: Oxford University Press).

Collier, Paul, and Jan W. Gunning, 1999, Trade Shocks in Developing Countries, Vol. 1 and 2 (Oxford and New York: Oxford university Press).

Combes, Jean-Louis, and Patrick Guillaumont, 2002, “Commodity Price Volatility, Vulnerability, and Development,” Development Policy Review, Vol. 20, pp. 25-39.

, Sylviane Guillaumont Jeanneney, and Pascale Motel Combes, 2000, “Ouverture sur l'Extérieur et Instabilité des taux de Croissance,” Revue Française d'Économie, Vol. 15, No. 1, pp. 3-33.

Dollar, David, 1992, “Outward-Oriented Developing Economies Really Do Grow More Rapidly: Evidence from 95 LDCs, 1976-85,” Economic Development and Cultural Change, Vol. 40, No. 3, pp. 523-44.

Deaton, Angus, 1999, “Commodity Prices and Growth in Africa," Journal of Economic Perspectives, Vol. 13, No. 3, pp. 23-40.

Easterly, William, Carlos A. Rodriguez, and Klaus Schmidt-Hebbel, 1994, Public Sector Deficits and Macroeconomic Performance (Washington: World Bank).

Edwards, Sebastian, 1998, “Openness, Productivity, and Growth: What Do We Really Know?” Economic Journal, Vol. 108, pp. 383-98. 
and Guido Tabellini, 1992, "Explaining Fiscal Policies and Inflation in Developing Countries,” Journal of International Money and Finance, Vol. 10, special issue, pp. S16-S48.

Fischer, Stanley, 1993, “The Role of Macroeconomic Factors in Growth,” Journal of Monetary Economics, Vol. 32, No. 3, pp. 485-512.

Griliches, Zvi, and Jerry A. Hausman, 1985, “Errors in Variables in Panel Data,” Journal of Econometrics, Vol. 31, pp. 93-118.

Guillaumont, Patrick, 1994, "Politique d'Ouverture et Croissance Economique : les effets de la croissance et de l'instabilité des exportations," Revue d'Economie du Développement, No. 1, pp. 91-114. and Sylviane Guillaumont Jeanneney, 1988, Strategies de développement comparées zone franc et hors zone franc (eds., Paris, Economica).

Loayza, Norman, Klaus Schmidt-Hebbel, and Luis Servén, 2000, “What Drives Private Saving Across the World?” The Review of Economics and Statistics, Vol. 82, No. 2, pp. 165-81.

Lindbeck, Assar, 1976, "Stabilization Policies in Open Economies with Endogenous Politicians,” American Economic Review, Vol. 66, No. 2, pp. 1-19.

Lensink, Robert, Hong Bo, and Elmer Sterken, 1999, "Does Uncertainty Affect Economic Growth? An Empirical Analysis,” 1999, Weltwirtschaftliches Archiv, Vol. 135, pp. 379-96.

Lucas, Robert E., and Nancy L. Stockey, 1983, “Optimal Fiscal and Monetary Policy in an Economy Without Capital,” Journal of Monetary Economics, Vol. 12, pp. 55-93.

Rodriguez, Francisco, and Dani Rodrik, 1999, “Trade Policy and Economic Growth: a Skeptic's Guide to Cross-National Evidence,” NBER Working Paper No. 7081 (Cambridge, Massachusetts: National Bureau of Economic Research).

Rodrik, Dani, 1999, The New Global Economy and Developing Countries: Making Openness Work, Overseas Development Council.

Rose, Andrew K., 2002, “Do WTO Members have More Liberal Trade Policy?” NBER Working Paper No. 9347 (Cambridge, Massachusetts: National Bureau of Economic Research).

Sachs, Jeffrey D., and Andrew M. Warner, 1995, “Economic Reform and the Process of Global Integration,” Brooking Papers on Economics Activity, Vol. 1, pp. 1-118. 
Savvides, Andreas, 1998, “Trade Policy and Income Inequality: New Evidence,” Economics Letters, Vol. 61, No. 3, pp. 365-72.

Schuknecht, Ludger, 1999, "Fiscal Policy Cycles and the Exchange Rate Regime in Developing Countries,” European Journal of Political Economy, Vol. 15, No. 3, pp. 569-80.

Talvi, Ernesto, and Carlos A. Végh , 2000, “Tax Base Variability and Procyclical Fiscal Policy,” NBER Working Paper No. 7499 (Cambridge, Massachusetts: National Bureau of Economic Research). 